\title{
NUTRITIONAL BEHAVIOR PATTERNS IN PROGRAM OF GIVING ADDITIONAL FOODS FOR INFANTS AGED 0-3 YEARS OF UNDER RED LINE
}

\author{
Frida Yunita Sari, Sri Hilmi Pujihartati
}

Universitas Sebelas Maret

srihilmi@staff.uns.ac.id

Article History

accepted 09/07/2018

approved 01/08/2018

published 17/09/2018

\section{Keywords}

The Pattern Of Behaviour

Of Foster Care Nutrition,

Toddler red down the line,

Restore additional feeding

\begin{abstract}
Malnutrition in the mother and the baby will have impact to health and intelligence, while the child's intelligence ank itself impact to availability of qualified human resources. Weak ability to provide mothers and families parenting will result in even less nutrition incidence of malnutrition in babies. This research aims to: 1) describes the patterns of behavior of nutrients, foster performed the mother on a toddler's bottom is red. 2) supplementary feeding program implementation the recovery on a toddler under the red line. In this study used the theory of George Homans, namely social exchange. This theory rests on the assumption that people engage in behavior to gain rewards or avoid punishment. So that actions taken person is dependent on or punishment is given against such action. This study uses qualitative methods, qualitative, descriptive approach to describe the actual situation on the ground. The selected informer is the mother of a toddler down red lines that receive additional feeding program of recovery, a midwife, dietitian and posyandu cadre clinic. Data collection using indepth interviews, observation, and documentation. The results showed that: 1) foster nutrition behavior patterns on a toddler under the red line is divided into knowledge include the feeding of pervades, the attitude of care and protection for children, psycho-social and parenting practices that include hygiene and environmental sanitation, health practices and health services search pattern and practice of breastfeeding and complementary feeding of breast milk. 2) Restore additional feeding program awarded to 4 toddler Toddler red down the line, extra food that is given in the form of raw food materials are unisex biscuits. There are constraints in the implementation of the programme including provision of additional food system i.e., a toddler who reluctantly taking Restore additional feeding as well as programs that have not been right on target.
\end{abstract}

Social, Humanities, and Education Studies (SHEs): Conference Series https://jurnal.uns.ac.id/shes

p-ISSN 2620-9284 e-ISSN 2620-9292 


\section{PENDAHULUAN}

Salah satu masalah kesehatan yang dihadapi bangsa Indonesia yaitu masalah gizi, dimana masalah gizi merupakan salah satu penentu kualitas sumber daya manusia. Manusia adalah kunci pembangunan, bahwa kualitas eksistensi manusia adalah ukuran yang sesunggguhnya bagi pembangunan dan bahwa di antara faktorfaktor yang mempengaruhi keadaan manusia, kecukupan gizi dalam makanan barangkali merupakan faktor penentu utama. Kekurangan gizi akan menyebabkan kegagalan pertumbuhan fisik dan perkembangan kecerdasan, serta menurunkan daya tahan tubuh yang berakibat meningkatnya angka kesakitan dan kematian.

Masa balita merupakan masa yang tergolong rawan dalam pertumbuhan dan perkembangan anak karena pada masa ini anak mudah sakit hingga dapat menyebabkan kurang gizi. Pada masa balita ini perkembangan kemampuan berbahasa, kreativitas, kesadaran sosial, emosional, dan intelegensi berjalan sangat cepat dan merupakan landasan perkembangan berikutnya. Perkembangan moral serta dasar-dasar kepribadian juga dibentuk pada masa ini. Selain itu nutrisi yang tepat dan lengkap akan memberikan dampak yang positif bagi tumbuh kembang otak dan juga fisik. Balita yang kurang terpenuhi kebutuhan nutrisinya dapat mengakibatkan dampak negatif bagi balita itu sendiri seperti kejadian gizi kurang dan gizi buruk. Oleh karena itu masa balita merupakan usia penting dalam tumbuh kembang anak secara fisik. Masa balta ini merupakan masa yang menentukan dalam tumbuh kembangnya, yang akan menjadi dasar terbentuknya manusia seutuhnya.

Lemahnya kemampuan ibu dan keluarga untuk memberikan pola asuh akan berakibat pada kejadian gizi kurang bahkan gizi buruk pada balita. Kualitas pengasuhan yang diberikan ibu mempunyai peranan penting bagi perkembangan anak. Anak balita yang memperoleh kualitas pengasuhan yang lebih baik, kemungkinan besar akan memiliki angka kesakitan yang rendah dan status gizi yang baik.

Pola asuh anak sendiri merupakan kemampuan keluarga dan masyarakat untuk menyediakan waktu, perhatian dan dukungan terhadap anak agar dapat tumbuh dan berkembang dengan sebaik-baiknya baik fisik, mental dan sosial berupa sikap dan perilaku ibu atau pengasuh lain dalam hal kedekatannya dengan anak, memberikan makan, merawat kebersihan dan memberi kasih saying (Zeitlin, 2000). Pola asuh gizi merupakan asupan makan dalam rangka menopang tumbuh kembang fisik dan biologis balita secara tepat dan berimbang (Eveline \& nanang D, 2010 : 11). Pola asuh gizi juga merupakan bagian dari pola asuh anak yaitu praktik di rumah tangga yang diwujudkan dengan tersedianya pangan dan perawatan kesehatan serta sumber lainnya untuk kelangsungan hidup, pertumbuhan dan perkembangan anak (Zeitlin, 2000).

Masalah gizi merupakan salah satu penentu kualitas sumber daya manusia. Status gizi balita yang mana merupakan generasi penerus bangsa tentunya mendapat perhatian lebih, baik dari pemerintah maupun masyarakat luas. Hal tersebut dibuktikan dengan berbagai upaya yang dilakukan oleh pemerintah melalui program-program terkait Kesehatan Ibu dan Anak, maupun masyarakat terutama orang tua perihal pola asuh untuk mengatasi kasus balita gizi kurang. Adapun upaya penanggulangan gizi kurang pada balita yang dilakukan oleh pemerintah antara lain melalui program PMT-P balita gizi kurang.

\section{Pola Perilaku}

\section{TINJAUAN PUSTAKA}

Pola merupakan model yang digunakan sebagai acuan dalam membentuk suatu sikap hingga dapat menghasilkan sebagaimana yang diharapkan. Dalam sosiologi perilaku dianggap sebagai tindakan, tingkah laku dimiliki oleh manusia dan dipengaruhi oleh adat, sikap, emosi, nilai, etika dan kekuasaan. Perilaku juga diartikan sebagai tindakan yang merupakan tingkah laku yang dibentuk oleh pelaku sebagai ganti respon 
yang didapat dari dalam dirinya. Jadi pola perilaku adalah kelakuan seseorang yang sudah tersusun atau tertata karena proses dari kelakuan tersebut dilakukan berulangulang sehingga pola perilaku hampir sama dengan kebiasaan. Menurut Skinner sebagaimana dikutip oleh Soekidjo Notoatmojo (2010), perilaku merupakan respon atau reaksi seseorang terhadap rangsangan dari luar (stimulus). Perilaku terjadi melalui proses adanya stimulus terhadap organisme dan kemudian organisme tersebut merespon, maka teori Skinner ini disebut teori "S-O-R" (Stimulus-OrganismeRespons). Berdasarkan batasan dari Skinner tersebut, maka dapat didefinisikan bahwa perilaku adalah kegiatan atau aktivitas yang dilakukan oleh seseorang dalam rangka pemenuhan keinginan, kehendak, kebutuhan, nafsu dan sebagainya. Kegiatan ini mencangkup Kegiatan kognitif, Kegiatan emosi dan Kegiatan konasi .

\section{Pola Asuh Gizi}

Pola asuh gizi merupakan bagian dari pola asuh anak yaitu praktik di rumah tangga yang diwujudkan dengan tersedianya pangan dan perawatan kesehatan serta sumber lainnya untuk kelangsungan hidup, pertumbuhan dan perkembangan anak (Zeitlin, 2000). Masalah gizi dipengaruhi oleh salah satunya adalah pola asuh ibu terhadap anaknya. lemahnya kemampuan ibu dan keluarga untuk memberikan pola asuh akan berakibat pada kejadian gizi kurang bahkan gizi buruk pada anak balita. Menurut LIPI (2000), Aspek kunci pola asuh gizi meliputi Perawatan dan perlindungan Bagi Anak, Pemberian Makan, Pengasuhan Psiko-Sosial, Kebersihan Diri dan Sanitasi Lingkungan, Praktik Kesehatan dan Pola Pencarian Pelayanan Kesehatan, serta Praktik Menyusui dan Pemberian Makanan Pendamping ASI.

\section{Program Pemberian Makanan Tambahan Pemulihan (PMT-P)}

Menurut Kementerian Kesehatan RI (2011), Program Pemberian Makanan Tambahan merupakan salah satu program intervensi bagi balita yang menderita gizi kurang dan gizi buruk, termasuk balita bawah garis merah. Makanan Tambahan adalah makanan bergizi sebagai tambahan selain makanan utama bagi kelompok sasaran guna memenuhi kebutuhan gizi. Menurut Persagi (2009), pemberian tambahan makanan di samping makanan yang dimakan sehari-hari dengan tujuan memulihkan keadaan gizi dan kesehatan. Program Pemberian Makanan Tambahan (PMT-P) diberikan kepada anak gizi buruk dan gizi kurang yang jumlah harinya tertentu dengan tujuan untuk meningkatkan status gizi anak. Ibu yang memiliki anak di bawah lima tahun yang menderita gizi kurang atau gizi buruk diberikan satu paket PMT Pemulihan. Pemberian makanan tambahan pemulihan dapat berupa PMT pemulihan lokal yaitu bahan makanan lokal yang diolah dirumah tangga atau disebut juga PMT Pemulihan Dapur Ibu dan PMT Pemulihan pabrikan yaitu PMT pemulihan hasil olahan pabrik, seperti susu dan biskuit.

\section{Balita Bawah Garis Merah (BGM)}

Menurut Departemen Kesehatan (2005) Balita BGM adalah balita yang saat ditimbang berat badannya berada pada garis merah atau di bawah garis merah pada Kartu Menuju Sehat (KMS). KMS adalah kartu yang memuat kurva pertumbuhan normal anak berdasarkan indeks antropometri berat atau tinggi badan menurut umur, mencatat pemberian kapsul vitamin A serta vaksinasi. Jika anak berada pada BGM maka diperlukan tindakan kewaspadaan "warning" agar anak tidak mengalami menderita gangguan pertumbuhan dan penyakit infeksi serta perhatian pada pola asuh agar lebih ditingkatkan. Berat Badan BGM bukan menunjukkan keadaan gizi buruk tetapi sebagai peringatan untuk konfirmasi dan tindak lanjut.

\section{Lokasi Penelitian}

\section{METODE PENELITIAN}

Dalam penelitian ini, peneliti mengambil lokasi di desa Kebonharjo, Kecamatan Polanharjo, Kabupaten Klaten. Adapun alasan pemilihan lokasi tersebut adalah karena pengalaman peneliti yang telah melakukan berbagai kegiatan yang berkaitan dengan 
balita bawah garis merah yang merupakan salah satu program dari instansi tempat magang penulis yaitu yayasan Gita Pertiwi.

\section{Tahapan Penelitian}

1. Persiapan Penelitian: Membuat surat ijin penelitian; Penyusunan instrumen penelitian (interview guide)

2. Pelaksanaan Penelitian: Penelitian ini merupakan jenis penelitian deskriptif kualitatif. Teknik pengumpulan data menggunakan teknik wawancara mendalam, observasi, serta di lengkapi dengan dokumentasi; Untuk menguji data menggunakan triangulasi sumber. Sedangkan teknik analisis data menggunakan teknik analisis interaktif yang dimulai dengan pengumpulan data, reduksi data, penyajian data, penarikan kesimpulan.

\section{HASIL PENELITIAN DAN PEMBAHASAN \\ Pola Perilaku Asuh Gizi Pada Balita Bawah Garis Merah}

Pengasuhan merupakan faktor yang sangat erat kaitannya dengan pertumbuhan dan perkembangan anak berusia di bawah lima tahun. Seorang ibu memegang peranan penting dalam pengasuhan anaknya. Selain pola asuh, asupan makanan juga penting dalam tumbuh kembang anak karena masa anak usia 1-5 tahun (balita) adalah masa dimana anak masih sangat membutuhkan suplai makanan dan gizi dalam jumlah yang memadai. Hal tersebut berdampak pada status gizi anak, sebab semakin banyak kandungan gizi dalam makanan yang diberikan pada anak maka anak tersebut akan mempunyai status gizi baik dan sebaliknya jika anak kurang mendapat asupan makanan yang bergizi maka anak tersebut dapat beresiko mempunyai status gizi kurang. Status gizi balita salah satunya dipengaruhi oleh praktik pola asuh gizi yang dilakukan dalam rumah tangga yang diwujudkan dalam tersedianya pangan dan perawatan dan perkembangan anak.

Pola asuh gizi yang diterapkan ibu terhadap balita bawah garis merah terdiri dari beberapa aspek kunci. Yang pertama yaitu perawatan dan perlindungan bagi anak, disini mayoritas ibu sudah tanggap dalam merawat anaknya ketika jatuh sakit. Mereka memberikan perawatan sendiri di rumah sebelum membawa anaknya berobat ke dokter, bidan setempat maupun puskesmas. Perawatan yang mereka lakukan yaitu dengan memberikan obat yang dibelinya sendiri di apotek atau toko.

Pengasuhan psiko-sosial yang dilakukan ibu kepada anaknya ini terwujud dalam pola interaksi anak dengan orang tua yang terdiri dari cinta dan kasih sayang serta interaksi antar ibu dan anak. Interaksi antara ibu dan anak ini salah satunya dapat terlihat dari cara mengasuh atau bagaimana ibu mengawasi anaknya setiap harinya. Dalam penelitian ini diketahui bahwa tidak semua ibu sepenuhnya mengasuh atau mengawasi anakya setiap harinya. Beberapa ibu mengasuh anaknya sambil bekerja di rumah seperti mengelem dompet, mengelem kipas dan menjaga konter pulsa. Aktifitas bekerja tersebut yang terkadang berpengaruh terhadap kewajiban ibu dalam mengasuh anaknya. Ditambah lagi dengan fakta bahwa beberapa ibu masih tinggal satu atap atau rumahnya masih berdekatan dengan orang tuanya atau mertuanya yang berdampak pula pada pola pengasuhan yang kemudian bukan hanya dilakukan oleh ibu tetapi juga oleh nenek.

Pola asuh gizi disini juga mencangkup kebersihan diri dan sanitasi lingkungan sebab perilaku kesehatan merupakan salah satu penyebab atau resiko utama penyebab masalah gizi. Dan peran orang tua dalam proses pertumbuhan dan perkembangan anak adalah dengan membentuk kebersihan diri dan sanitasi lingkungan yang sehat. Dari hasil penelitian diketahui bahwa belum sepenuhnya ibuibu balita menerapkan perilaku hidup bersih dan sehat dalam mengasuh balitanya. Hal ini terlihat dari kebiasaan ibu mengajarkan anaknya mencuci tangan yang belum sesuai dengan langkah-langkah yang telah dianjurkan dan terkadang tidak menggunakan sabun saat mencuci tangan. Selain itu juga kesadaran untuk menjaga 
lingkungan rumah agar bersih dan sehat dirasa masih kurang, padahal dengan rutin membersihkan rumah seminggu sekali dapat memberantas jentik-jentik di rumah. Dan juga belum setiap harinya menerapkan menu sehat salah satunya dengan mengonsumsi buah-buahan yang baik untuk tubuh, hal ini juga berkaitan dengan praktik pemberian makan yang dilakukan ibu terhadap anaknya.

Nutrisi gizi memegang peranan penting dalam perkembangan seorang anak. Untuk itu perlu bagi orang tua dalam memenuhi kebutuhan gizi anak dengan memberikan asupan makanan yang bergizi. Untuk mengetahui asupan makanan yang diberikan ibu balita kepada balita BGM dapat dilihat melalui frekuensi pemberian makan, komposisi dan porsi makanannya serta cara pengolahan dan penyajian makanan. Berdasarkan hasil wawancara didapati bahwa frekuensi pemberian makan yang dilakukan oleh ibu bergantung pada permintaan anaknya, jadi ibu tidak mempunyai jadwal tertentu ketika akan memberikan makan untuk anaknya. Untuk komposisi atau menu makanan, beberapa ibu biasanya menyiapkan komposisi makanan dan porsi makanannya tergantung dengan keinginan anak. Karena mengikuti permintaan anak tersebut terkadang justru ibu memberikan makanan yang kurang bergizi bahkan ada yang memberikan makanan instan kepada anaknya karena menuruti permintaan anak tanpa mempertimbangkan kandungan gizi dalam makanan. Dan mayoritas ibu balita belum kreatif dalam menyajikan makanan untuk anaknya karena ibu menyiapkan satu menu makanan yang diperuntukkan bagi semua anggota keluarga, jadi untuk makanan balitanya tidak ada pengolahan tersendiri yang dilakukan, mereka hanya membedakan untuk makanan balitanya adalah makanan yang tidak pedas.

Praktik kesehatan dan pola pencarian pelayanan kesehatan yang merupakan salah satu aspek kunci pola asuh gizi. Dari hasil penelitian diketahui bahwa sebagian ibu tergolong aktif mengikuti kegiatan posyandu sedangkan sebagian lainnya tergolong tidak aktif dalam kegiatan timbangan balita saat posyandu maupun kelas balita. Ada beberapa faktor yang membuat ibu tidak aktif dalam kegiatan timbangan posyandu maupun kelas balita diantaranya yaitu anaknya yang sering rewel ketika diajak mengikuti kegiatan tersebut. Selain itu juga karena ibu merasa malu sebab berat badan anak yang tidak mengalami kenaikan yang signifikan setiap kali timbangan.

Kemudian praktik menyusui dan pemberian MP-ASI yang meliputi pemberian makanan/minuman prelaktal, pemberian kolostrum, pemberian ASI, pemberian MP-ASI serta praktik penyapihan. Dari hasil penelitian diketahui bahwa sebagian besar ibu memberikan makanan/minuman prelaktal berupa susu formula kepada bayinya sesaat setelah lahir. Hal tersebut dilakukan karene beberapa alasan salah satunya yaitu masalah puting tenggelam atau sedikitnya ASI yang dihasilkan. Untuk praktik pemberian kolostrum hampir semua ibu memberikan susu pertama yang keluar tersebut untuk bayinya. Tetapi ada juga ibu yang membuang kolostrumnya karena ketidaktauan akan manfaat dari kolostrum bagi bayinya. Lalu praktik pemberian ASI yang dilakukan ibu ada yang memberikan ASI eksklusif kepada bayinya hingga berusia 6 bulan tapi ada juga yang memilih praktik pemberian ASI non eksklusif. Dalam memberikan MP-ASI ada ibu yang sudah memberikan makanan pendamping saat bayi masih berumur 4 bulan dan 5 bulan. Sedangkan ibu lainnya memberikan MP-ASI setelah bayi berusia 6 bulan. Sedangkan untuk praktik penyapihan sebagian ibu sudah melakukan pratik penyapihan karena beranggapan bahwa batas usia anak menyusui adalah 2 tahun.

\section{Pelaksanaan Program Pemberian Makanan Tambahan Pemulihan Pada Balita Bawah Garis Merah}

Pelaksanaan program pemberian makanan tambahan pemulihan di desa Kebonharjo ditujukan kepada balita dengan berat badan di bawah garis merah pada grafik pertumbuhan Kartu Menuju Sehat (KMS). Sasaran program tersebut ditentukan berdasarkan hasil penimbangan balita di posyandu setiap bulannya. Dan balita 
penerima program PMT-P di desa Kebonharjo diantaranya yaitu Charles, Muhammad Abizar Alfat, Azka Aulian Abqary, dan Nabil Afkar Fadil. Berbeda dari program PMT-P yang diberikan oleh CSR Aqua melalui Gita Pertiwi yang dilakukan selama 4 bulan, program PMT-P dari Puskesmas diberikan tidak dalam kurun waktu tertentu. Namun jika dilihat dari aturan pemerintah, program PMT-P seharusnya diberikan kepada balita selama 90 hari atau selama 3 bulan.

PMT-P berupa bahan mentah diberikan seminggu sekali yang mencangkup makanan 4 bintang seperti beras, roti, sayur-sayuran, telur, ikan, ayam, buah dan sebagainya. Sedangkan PMT-P berupa biskuit diberikan kapan saja ketika ada permintaan dari ibu balita karena faktanya tidak banyak balita terutama balita BGM yang menyukai biskuit PMT-P tersebut. Hal itulah yang menjadi kendala dalam pelaksanaan program PMT-P yaitu banyak balita BGM yang menolak mengonsumsi makanan tambahan berupa biskuit tersebut karena bosan dengan biskuit yang tidak bervariasi dan karena kandungan susudalam biskuit yang sangat terasa sehingga membuat balta BGM merasa eneg atau mual. Karena mayoritas balita BGM tidak menyukai biskuit PMT-P tersebut alhasil anggota keluarga lain yang mengonsumsi biskuit PMT-P dan dapat dikatakan bahwa progam PMT-P tersebut tidak tepat sasaran. Untuk memantau perkembangan berat badan balita selama program PMT-P, bidan desa dan kader posyandu akan melakukan kunjungan rumah setiap 2 minggu sekali untuk menimbang berat badan, mengukur tinggi badan dan mengukur lingkar lengan atas. Dan hasil penelitian menunjukan ada balita yang mengalami kenaikan berat badan selama PMT-P sehingga berdampak pada status gizinya yang menjadi baik. Namun masih ada balita yang memiliki berat badan masih berada di pita kuning dan dibawah garis merah sehingga perlu mendapatkan penanganan lebih lanjut.

\section{SIMPULAN}

Perubahan status gizi balita BGM bukan hanya karena pemberian makanan tambahan pemulihan untuk balita BGM tersebut tetapi juga karena pola asuh gizi yang dilakukan ibu. Hal tersebut dapat dilihat dalam aspek-aspek kunci pola asuh gizi yang telah dijelaskan.

1. Pola perilaku asuh gizi pada balita bawah garis merah

Penyebab gizi kurang dipengaruhi oleh beberapa faktor yang saling terkait dan salah satu diantaranya yaitu pola pengasuhan. Status gizi dan perkembangan balita dipengaruhi oleh pengasuhan orang tua, terutama kualitas pengasuhan yang diberikan oleh ibu yang berperan penting bagi pertumbuhan dan perkembangan anak. Semakin baik pola asuh gizi yang diberikan ibu kepada balitanya, semakin besar pula kemungkinan balita tersebut memiliki angka kesakitan yang rendah serta status gizi yang baik. Pola perilaku asuh gizi pada balita bawah garis merah terbagi menjadi pengetahuan meliputi pemberian makan, sikap meliputi perawatan dan perlindungan bagi anak, pengasuhan psiko-sosial serta praktik yang meliputi kebersihan diri dan sanitasi lingkungan, praktik kesehatan dan pola pencarian pelayanan kesehatan dan praktik menyusui dan pemberian makanan pendamping ASI.

2. Pelaksanaan program pemberian makanan tambahan pemulihan pada balita bawah garis merah.

Selain pola asuh gizi yang diterapkan ibu, pemberian makanan tambahan pemulihan juga berdampak pada status gizi balita bawah garis merah yang terlihat dari hasil penelitian berupa data timbangan berat badan balita BGM selama pemberian makanan tambahan pemulihan. PMT-P yang diberikan berupa biskuit dan bahan makanan mentah. Dan hasil penelitian menunjukkan ada balita yang mengalami kenaikan berat badan selama PMT-P sehingga berdampak pada status gizinya yang menjadi baik. Namun masih ada balita yang memiliki berat badan masih berada di pita kuning dan dibawah garis merah sehingga perlu mendapatkan penanganan lebih lanjut. 


\section{DAFTAR PUSTAKA}

Almatsier Sunita, Soetardjo Susirah, Soekarti Moesijanti. 2011. Gizi Seimbang dalam Daur Kehidupan. Jakarta (ID): PT. Gramedia Pustaka Utama.

Adriani, Merryana dan Kartika, Vita. 2011. Pola Asuh Makan Pada Balita Dengan Status Gizi Kurang di Jawa Timur, Jawa Tengah dan Kalimantan Tengah. Buletin Penelitian Sistem Kesehatan Vol. 16 No. 2. Surabaya

Arikunto, S. 2010. Prosedur Penelitian Suatu Pendekatan Praktik. Jakarta : Rineka Cipta.

Berg, Alan. 1986. Peranan Gizi dalam Pembangunan Nasional. Jakarta : Rajawali.

Claire Farrow, Jacqueline Blissett \& Emma Haycraft. 2011. Does child weight influence how mothers report their feeding practices?. International Journal Of Pediatric Obesity Vol 6, Issue 3-4)

Dinas Kesehatan Klaten. 2016. Profil Dinas Kesehatan Klaten Tahun 2015. Klaten : Dinkes Klaten.

Anonymous. 1998. Buku Pedoman ASI Eksklusif Bagi Petugas. Semarang

Kementrian Kesehatan RI. 1999. Rencana Pembangunan Kesehatan Menuju Indonesia Sehat 2010. Jakarta

2000. Gizi dan Kesehatan Saluran Pencernaan pada Bayi dan Anak. Jakarta : Nestle Nutrilon.

Kementrian Kesehatan RI. 2002. Pemantauan Pertumbuhan Balita. Jakarta.

Kementrian Kesehatan RI. 2003. Penimbangan Balita. Padang : Depkes RI.

Kementrian Kesehatan RI. 2005. Standar Pemantauan Pertumbuhan Balita. Jakarta : Dirjen Kesmas.

Kementrian Kesehatan RI. 2011. Panduan Penyelenggaraan Pemberian Makanan Tambahan Pemulihan Bagi Balita Gizi Kurang (BOK). Jakarta

Ebrahim, G. J. 1988. IImu Kesehatan Anak di Daerah Tropis. Jakarta : Yayasan Esensia Medika.

Eveline dan Nanang. 2010. Panduan Pintar Merawat Bayi dan Balita. Jakarta : PT. Wahyu Media.

Gibson, SR. 1990. Principle of Nutritional Assesment. London : Oxford University Press.

H.B. Sutopo. 2002. Metodologi Penelitian Kualitatif. Surakarta : UNS Press.

Istiany, Ari, dkk. 2013. Gizi Terapan. Bandung: PT. Remaja Rosdakarya.

Krisnatuti, D., Yenrina R. 2000. Menyiapkan Makanan Pendamping ASI. Jakarta : Puspa Swara.

Kristi E., Poerwandari. 1998. Pendekatan Kualitatif dalam Penelitian Psikologi. Jakarta : LPSP3 Psikologi UI.

LIPI. 2000. Widyakarya Nasional Pangan dan Gizi VII. Jakarta

Lupitasari, Widian. 2011. Pola Perilaku Asuh Kesehatan Pada Anak Balita Di Keluarga Lapisan Bawah. Skripsi. Universitas Sebelas Maret.

Mahgoub, Salah E.O., Maria Nnyepi, Theodore Bandeke. 2006. Factors Affecting Prevalence Of Malnutrition Among Children Under Three Years Of Age In Botswana. African Journal Of Food Agriculture Nutrition And Development Vol 6 No. 1. Nairobi Kenya.

Marimbi, Hanum. 2010. Tumbuh Kembang, Status Gizi dan Imunisasi Dasar Pada Anak Balita. Yogyakarta : Nuha Medika.

Marlina. 2012. Hubungan Asupan Zat Gizi dan Aktifitas Fisik Terhadap Diabetes Mellitus Tipe 2 pada Pegawai Negeri Sipil Dinas Kesehatan Provinsi Kalimantan Barat. Skripsi. Universitas Esa Unggul 
Moeleong, Lexy. 2002. Metodologi Penelitian Kualitatif. Bandung : PT. Remaja Rosdakarya.

--------. 2007. Metodologi Penelitian Kualitatif. Bandung : PT. Remaja Rosdakarya. Nursalam, 2005. Aspek Tumbuh Kembang Pada Balita. Jakarta. EGC

Notoatmodjo, S. 1997. Ilmu Kesehatan Masyarakat Prinsip-prinsip Dasar. Jakarta : Rineka Cipta.

- 2007. Promosi Kesehatan dan IImu Perilaku. Jakarta : Rineka Cipta.

2010. Metodologi Penelitian Pengetahuan, Sikap, dan Perilaku Manusia.

Yogyakarta : Nuha Medika.

Oemar, Rindu dan Astrid Novita. 2015. Pola Asuh dalam Kesehatan Anak Pada lbu Buruh Pabrik. Jurnal Kesehatan Masyarakat. Universitas Negeri Semarang.

Pudjiadi, S. 2005. IImu Gizi Klinis Pada Anak, Edisi 4. Jakarta : Balai Penerbit FKUI.

Persagi. 2009. Tabel Komposisi Pangan Indonesia. Jakarta: PT Elex Media Komputindo.

Prasetyawati, Arsita Eka. 2012. Kesehatan lbu dan Anak (KIA) dalam Milenium Development Goals (MDGs). Yogyakarta : Nuha Medika.

Ritzer, dan Goodman J. Douglas. 2010. Teori Sosiologi Modern. Jakarta : Kencana.

Rosmana, Dadang, 2003. Hubungan Pola Asuh Gizi dengan Status Gizi Anak Usia 624 Bulan di Kabupaten Serang Propinsi Banten Tahun 2003. Tesis Program Pasca Sarjana FKM UI. Depok

Rachmawati, U., Setyaningsih, P., Chabibah, N. 2013. Karakteristik Balita Dengan Berat Badan Di Bawah Garis Merah (Bgm) Di Kecamatan Bojong Kabupaten Pekalongan. STIKES Muhammadiyah Pekajangan Pekalongan. Skripsi.

Rohimah I, Etti S, Ernawati N. 2014. Analisis energi dan protein serta uji daya terima biskuit tepung labu kuning dan ikan lele. Jurnal USU.

Savage, King. 1991. Menolong Ibu Menyusui. Terjemahan Sukwan Handali. Jakarta : Gramedia Pustaka

Satoto. 1990. Pertumbuhan dan perkembangan anak umur 0-18 bulan di Kecamatan Mlonggo, Kabupaten Jepara, Jawa Tengah. Semarang : Universitas Diponegoro.

Sihadi, Sudjasmin, Suhartato, dan Latifah, T. 2000. Gambaran Perubahan Status Gizi Anak Balita Gizi Buruk Pengunjung Klinik Bogor. In: Suparmanto, S,A,S, et al, eds. Buletin Penelitian Kesehatan Vol 28. Jakarta : Balai Penelitian dan Pengembangan Kesehatan Depkes RI.

Subekti, Sri dan Yulia, Cica. 2012. Pengetahuan Gizi dan Pola Asuh Ibu Anak Balita Gizi Kurang di Kelurahan Pasteur, Kecamatan Sukajadi, Bandung. Invotec Vol VIII No. $1: 58-74$. Bandung

Sutomo, Budi dan Anggraini, Dwi Yanti. 2010. Menu Sehat Alami Untuk Balita \& Batita. Jakarta: PT. Agromedia Pustaka.

Suhardjo. 1986. Pangan, Gizi dan Pertanian. Jakarta : UI Press.

-------. 1996. Berbagai Cara Pendidikan Gizi. Jakarta : Bumi Aksara.

Supariasa, I Dewa Nyoman. 2001. Penilaian Status Gizi. Jakarta : Buku Kedokteran EGC.

Supariasa IDN, Fajar I, Bachyar B. 2002. Penilaian Status Gizi. Jakarta : EGC

------. 2013. Penilaian Status Gizi. Jakarta : EGC.

Soetjningsih. 1995. Tumbuh Kembang Anak. Jakarta : Buku Kedokteran EGC -------. 1998. Tumbuh Kembang Anak. Jakarta : EGC. 
Soekirman. 2000. IImu Gizi dan Aplikasinya. Jakarta : Direktorat Jenderal Pendidikan Tinggi, Departemen Pendidikan Nasional.

UNICEF. 1998. The State of The World's Children. Oxford University press.

Kementrian Kesehatan RI. 2012. Ringkasan Kajian Gizi. Jakarta : Pusat Promosi Kesehatan - Kementrian Kesehatan RI.

Veeger, K. J. 1993. Realitas Sosial. Jakarta : Gramedia Pustaka.

Waryana. 2010. Gizi Reproduksi. Yogyakarta : Pustaka Rihama.

Winarno, F. G. 1990. Protein, Sumber dan Peranannya. Jakarta : Gramedia Pustaka.

Widian Lupitasari. 2011. "Pola Perilaku Asuh Kesehatan Pada Anak Balita di Keluarga Lapisan Bawah". Fakultas IImu Sosial dan IImu Politik. Universitas Sebelas Maret. Surakarta.

Yunus, Hadi Sabari. 2010. Metodologi Penelitian Wilayah Kontemporer. Yogyakarta : Pustaka Pelajar.

Zeitlin M. 2000. Gizi Balita di Negara-Negara Berkembang, Peran Pola Asuh Pemanfaatan Hasil Studi Penyimpangan Positif untuk Program Gizi. Widyakarya Nasional Pangan dan Gizi VII: 125-143. Jakarta: LIPI 